\title{
Interfaces between traditional urban drainage systems and water resources: case study - Rio Tavares and Morro das Pedras watersheds, Florianópolis, Brazil
}

\author{
E. Pacheco \& A. Finotti \\ Department of Sanitary and Environmental Engineering, \\ Federal University of Santa Catarina, Florianópolis, Brazil
}

\begin{abstract}
This study identified and systematized the interfaces between traditional urban drainage systems and water resources with the aim of providing decision-makers with the scientific and technical knowledge required to develop an integrated urban water management strategy. After the collection of technical documents on the sanitation infrastructure of the Rio Tavares and Morro das Pedras watersheds, in Florianópolis, Brazil, the stormwater drainage system of the region was mapped and the environmental characterization described, dividing the two basins into 6 regions for analytical purposes. The systematization of the documents resulted in a synthesis map generated by cross-checking the information regarding the current drainage system, the hydrography, and the vulnerability of the Campeche aquifer (DRASTIC and GOD methods), thus revealing the interfaces between stormwater management and surface and groundwater resources. The diagnostic phase identified the use of structural measures for the straightening and/or channelization of parts of the river. In the analyzed orthophotos, flooding points were observed downstream of the watersheds. The stormwater effluents are discharged, without any pretreatment, into the mangroves and sandbanks, or infiltrate through the drainage pipe, creating points of contaminant injection in the Campeche aquifer. This study suggests the creation of a unified database for the drainage network, hydrography and urban infrastructure, as well as the standardization of projects by means of sanitation, water resource, and stormwater management plans. Furthermore, qualitative and quantitative monitoring projects for water resources
\end{abstract}


and drainage systems are developed in order to assess the real impacts of urban drainage systems on surface and groundwater resources.

Keywords: urban drainage systems, water resources, integrated management.

\section{Introduction}

Several spheres of urban planning should be considered in order to achieve sustainable urban development. Water management is one of the challenges of urbanization. Drainage water, natural water bodies, water used for public supply, wastewater dumping, and groundwater are some of the aspects involved in an integrated approach to stormwater management.

Brazil is going through a time of change as far as the territorial unit for water management is concerned. The traditional political-administrative division was replaced by the watershed as the appropriated scale for planning after the passage of the Water Resources Act of 1997 [1]. In 2007, new legislation was enacted establishing the Brazilian Basic Sanitation Policy, which emphasizes the watershed as the organizing unit also recommended for sanitation [2]. Therefore, two management units coexist in the country, leading to a multitude of realities depending on the stage of implementation of these new guidelines for water and sanitation spread out over its 5564 municipalities, as opposed to older laws that used other units for organizing geographic space.

The definition of the planning unit is decisive in the specific case of urban drainage systems. Drainage is an interface between the occupation of urban space and land use and stormwater runoff. As a general rule, master plans are highly susceptible to real estate speculation and may disregard important aspects of environmental variables. Urban drainage planning and management based only on the road system is a misstep that, despite extensive documentation to the contrary [3, 4], is still being made in many cities throughout the world, aggravating flooding problems.

In this paper, we present a case study from the city of Florianópolis in southern Brazil (fig. 1). We observed in this region a lack of effective management practices for the multiple and integrated use of water resources and for the sanitation system, as well as the lack of cohesion between the latter and other organizational systems of the urban environment. According to the Integrated Municipal Basic Sanitation Plan (Plano Municipal Integrado de Saneamento Básico, PMISB [5]), which was developed by the local government of the city of Florianópolis, sanitation services have proved to be deficient, particularly as regards urban sewerage and drainage systems. The regularity of investments led to higher rates of public water supply and solid waste collection.

This paper deals specifically with the District of Campeche, a coastal region located on the island of Florianópolis, which is one of the main tourist destinations in Brazil. The region has had a rapid and uncontrolled growth, with annual growth rates of up to $20 \%$ by the year 2000 (Engevix) [6], creating a gap between the urban infrastructure and the sustainable use of water resources.

In this study, we adopted a method based on the cross-checking of layers of information to determine and systematize the interfaces between traditional 
urban drainage systems implemented in the study area and water resources in the Rio Tavares and Morro das Pedras watersheds, which contribute water to the Campeche aquifer. The synthesis map created by means of the cross-checking procedure can serve as an important tool for the management of urban areas, as it combines information on the use and occupation of land, sanitation, and water management with a view to providing decision-makers with the technical and scientific knowledge required to develop an integrated water management strategy.

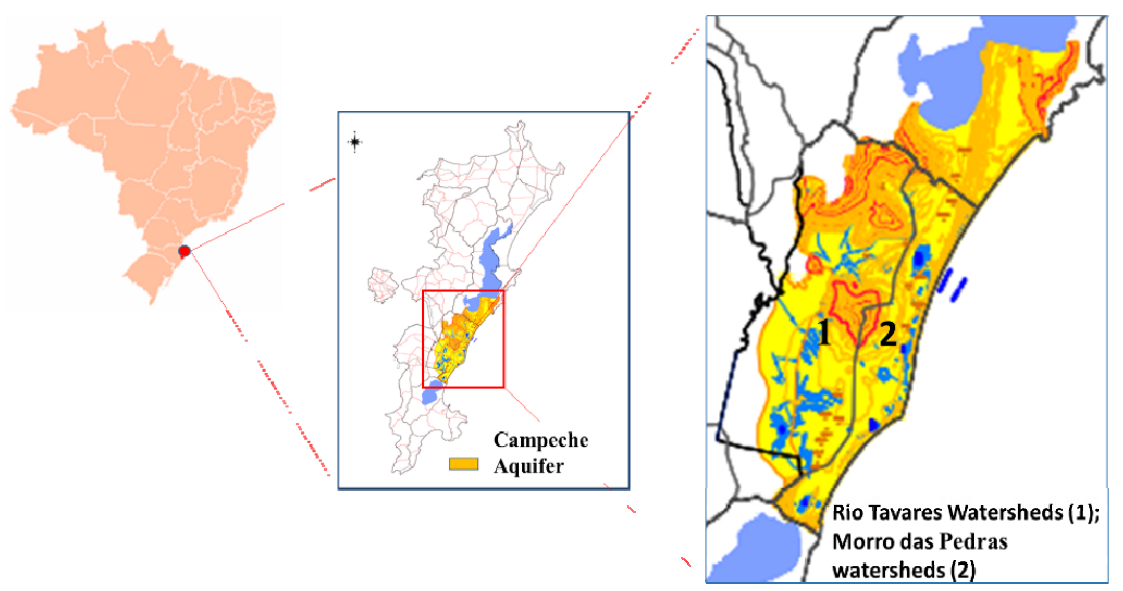

Figure 1: Definition of the study area.

\section{Methodology}

The study was conducted in three phases: collection of technical data on the study area; creation of base maps by combining layers of information; integration of base maps in a GIS environment and assessment of the management of the urban drainage system and water resources.

Phase 1: The collection of technical data was based on the information gathered from studies carried out in the region, as well as from technical documents and projects commissioned by the Municipality of Florianópolis (Prefeitura Municipal de Florianópolis, PMF). Site visits were made to public administrative bodies and the documents relevant to the study were requested. Some public documents were accessed directly on the websites maintained by the local government. Technical documents were found in several different locations depending on the administrative agency that had commissioned them (as shown in Table 1).

In the second phase, the maps obtained were prepared or maps were developed using the information found scattered through the records of the government bodies. We carried out the mapping of the geology, thickness of the unsaturated zone, areas at risk of organic contamination, critical areas of flooding, and 
vulnerability of the Campeche aquifer using the AutoCAD 2010 software package. The hydrographic map was constructed using field data and included the location of drainage channels and ditches. The map of the micro-drainage network was made from plans and descriptive memorandums, supplied by the Department of Public Works, of the paving and drainage projects for each of the streets in the study area. These data were fully dispersed and were gathered by identifying each street. AutoCAD 2010 was used to map out the drainage network.

In the third phase, a synthesis map was produced through the cross-checking of layers of information regarding the existing drainage network, the vulnerability of the Campeche aquifer, the location of CASAN's abstraction wells, and the location of water resources. This synthesis map allowed not only

Table 1: Data and documents compiled for the study.

\begin{tabular}{|c|c|c|}
\hline Document or sparse data & Agency & Relevance to the study \\
\hline $\begin{array}{l}\text { Aquifer vulnerability } \\
\text { assessment }\end{array}$ & $\begin{array}{l}\text { Santa Catarina State Water and } \\
\text { Sanitation Utility - CASAN }\end{array}$ & $\begin{array}{l}\text { Comprehensive study on the } \\
\text { vulnerability of the Campeche aquifer }\end{array}$ \\
\hline $\begin{array}{l}\text { Data on the drainage } \\
\text { system }\end{array}$ & Department of Public Works PMF & $\begin{array}{l}\text { Sparse, non-consolidated data on the } \\
\text { micro-drainage system }\end{array}$ \\
\hline PMISB & $\begin{array}{l}\text { Website of the Department of } \\
\text { Housing and Environmental } \\
\text { Sanitation }\end{array}$ & $\begin{array}{l}\text { Consolidated data on the macro-drainage } \\
\text { system of the city }\end{array}$ \\
\hline $\begin{array}{l}\text { Master plan of } \\
\text { Florianópolis }\end{array}$ & $\begin{array}{l}\text { Website of the Urban Planning } \\
\text { Institute (IPUF) }\end{array}$ & Urban occupation planning \\
\hline $\begin{array}{l}\text { Master plan of the } \\
\text { coastal resorts Decree- } \\
\text { Law No. 2193/85 } \\
\text { PMF/IPUF }\end{array}$ & $\begin{array}{l}\text { Urban Planning Institute of } \\
\text { Florianópolis }\end{array}$ & $\begin{array}{l}\text { Occupation planning with a view to } \\
\text { promoting tourism in beach areas }\end{array}$ \\
\hline
\end{tabular}

for the visualization of the interfaces between the physical means assessed, but also for the identification of management conflicts arising from the lack of integrated management arrangements for water resources. Based on the synthesis map, we were able to describe in more detail the 6 most vulnerable regions in the study area, namely: Lagoa Pequena, Riozinho do Campeche, Rio Tavares, Lagoa da Chica, Norbecker gated community, and Morro das Pedras. The analysis of the synthesis map and the conclusions drawn from the detailed study of the most vulnerable areas enabled us to outline the mitigation measures applicable to the case study of the Campeche region. Furthermore, we proposed management actions aimed at preventing new impacts of urban drainage systems on water resources.

\subsection{Characterization of the study area}

The region selected for study was the area that contributes water to the Campeche aquifer, as delimited by the planning units (unidades territoriais de planejamento, UTPs) proposed in the PMISB of the city of Florianópolis [5]. The study area covers the UTPs of Rio Tavares, Morro das Pedras, and Lagoa da Conceição (Fig. 1). The environmental aspects considered most relevant to the 
study were the hydrography, geology, geomorphology, and characterization of the Campeche aquifer. This area has been the subject of much conflict regarding land and natural resource use. The Campeche aquifer is unconfined and has been used as a source of water for public supply. At the same time, it also receives effluents discharged from urban drainage and alternative on-site sewer systems. The interest of tourists in the area is high, as is the level of real estate speculation. From an ecological point of view, the site features several environment types protected by law, such as mangroves, dunes, and restingas (sandbanks).

The hydrography of the study area consists primarily of coastal lagoons (Lagoa Pequena and Lagoa da Chica), which originate in the crystalline southern portion of the island of Florianópolis and drain into the plain of Campeche, the Campeche aquifer, and the Tapera and Rio Tavares Mangroves.

The study area is geologically composed of two main formations: the crystalline basement, represented by the granite rocks, and recent sand deposits, forming the geomorphological units of Serra Litorânea (coastal mountains) and Planície Costeira (coastal plain). Between the rock units, there is a sandy plain with mobile and fixed dunes, restingas and lagoon formations. The coastal plain extends in an east-west direction, with an approximate length of $11 \mathrm{~km}$ in the general NNE-SSW trend, until reaching the Tapera and Rio Tavares mangroves. This plain is mainly characterized by its fragile, unconsolidated sandy soil that accumulates water [6].

\subsubsection{Characterization of the Campeche aquifer}

The Campeche aquifer covers approximately $39.2 \mathrm{~km}^{2}$, occupying part of the Districts of Campeche, and the eastern half of the District of Lagoa da Conceição (Figure 1) (CASAN [7]). It is a predominantly unconfined aquifer system, composed of fine to medium sand, with a discontinuous pattern of intercalation of sand-clay levels. The study of the vulnerability of the aquifer discussed below was conducted using the GOD method. It is based on the evaluation of three parameters (Foster and Hirata [8]): groundwater occurrence, overall lithology, and depth to groundwater. By using this system, it is possible to find a numerical value for the study area by calculating the product of these three factors. Each of these factors is classified according to a specific scale in which values are normalized to a range between 0 and 1 .

$$
G O D=G . O . D
$$

The final values obtained through the method vary between 0 and 1 , and the closer the result of eqn (1) is to 1, the more vulnerable the aquifer is. According to the GOD method, the Campeche coastal aquifer system has a mean index value of natural vulnerability equal to 0.8 , within the range of extreme vulnerability. In some portions of the aquifer, there is an increase in vulnerability mainly due to two factors. The first of them are the thin unsaturated zones in areas with a partial upwelling of groundwater. The second factor is related to the recharge zones, particularly in mobile- and fixed-dune areas. 


\section{Results and discussion}

\subsection{Assessment of urban water bodies in the District of Campeche}

In Florianópolis, public water supply and sewerage services are provided by the Santa Catarina State Water and Sanitation Utility (Companhia Catarinense de Águas e Saneamento, CASAN). The water supply system consists of 13 wells for collecting groundwater and water from the Lagoa do Peri and Rio Tavares springs.

Among the UTPs included in the study, only that of Lagoa da Conceição is served by wastewater collection and treatment facilities, with a sewered population of $29.5 \%$. In the UTPs of Rio Tavares and Morro das Pedras, public sanitary sewers are not available [5]. In these instances, septic tanks, anaerobic filters, and leaching pits or infiltration ditches are used for individual, on-site sewage treatment.

Another important factor to be considered as far urban infrastructure is concerned is the relationship between Urban Drainage and water resources. According to the PMISB, the drainage system of Florianópolis largely took advantage of natural streams as a way to solve the stormwater runoff problem, thus contributing to their degradation. The main cause of flooding is the lack of an efficient drainage system combined with the unplanned occupation of the urban environment, in addition to numerous blockages in the natural flow of watercourses (Engevix [6]). The existing drainage system is also affected by illegal connections from residential sewer lines. The lack of proper inspection fuels this illicit practice.

Six critical points with flooding of macro-drainage channels of the UTPs of Rio Tavares and Morro das Pedras were identified in the analysis of the macrodrainage system presented in the PMISB [5]. The plan did not include the analysis of the micro-drainage system.

In the city of Florianópolis, improvements are made in the drainage system as paving work is completed, with the Department of Public Works of the local government being responsible for implementing and executing these projects. Drainage projects act as a complement to paving and do not include stormwater runoff planning. For this reason, it was necessary to develop a map of the microdrainage network using sparse data obtained from projects for each street in the area. The drainage system basically consists of structural measures: gutters, pipe galleries, ditches, and channels. It features water recharge devices, water abstraction and storage tanks, and stormwater infiltration structures such as leaching pits and retention and infiltration tanks that inject drainage water into the soil of the region, directly reaching the Campeche aquifer.

The adoption of these structural measures degrades in both a qualitative and quantitative way the water resources of the district of Campeche, mainly because of the lack of a sewerage system and the deficient drainage network resulting from poor urban planning. The application of structural strategies without any prior study or planning is prevalent in urban drainage. 


\subsection{Analysis of the impacts of stormwater management on water resources}

\subsubsection{Information cross-checking}

Once the map with the drainage network of Campeche was generated, it was cross-checked with the aquifer vulnerability map. A detailed study of the regions of greatest vulnerability in the aquifer was carried out and its results are described in fig. 2 .

The main features analyzed were the structural measures used for implementing the drainage network, the relationship between them and their influence on water bodies - rivers, lagoons and marshy areas - as well as their impacts on groundwater resources. We also evaluated the use of channels and their influence on the region's hydrography and investigated an increase in flooding caused by the channelization of river stretches implemented in an unplanned manner and for individual purposes. Below is a description of each of the regions identified in the synthesis map (Figure 2) supplemented by confirmatory field observations. The problems detected by using the map and the field data are summarized in the matrix presented in Table 2.

\subsubsection{Region1: Lagoa Pequena}

Lagoa Pequena has a total area of approximately $186,372 \mathrm{~m}^{2}$, being the most important upwelling of water table in the Campeche Plain, and, from a hydrogeological point of view, forming the Santa Catarina Island, a major subbasin [9]. When the lagoon overflows and laps into the secondary bed, the water runs off through a channel southeast of the lagoon and between the dunes, forming swamps that slowly seep into the Riozinho river and reach the Campeche beach. It features 3 abstraction wells for collecting water to supply its area of influence.

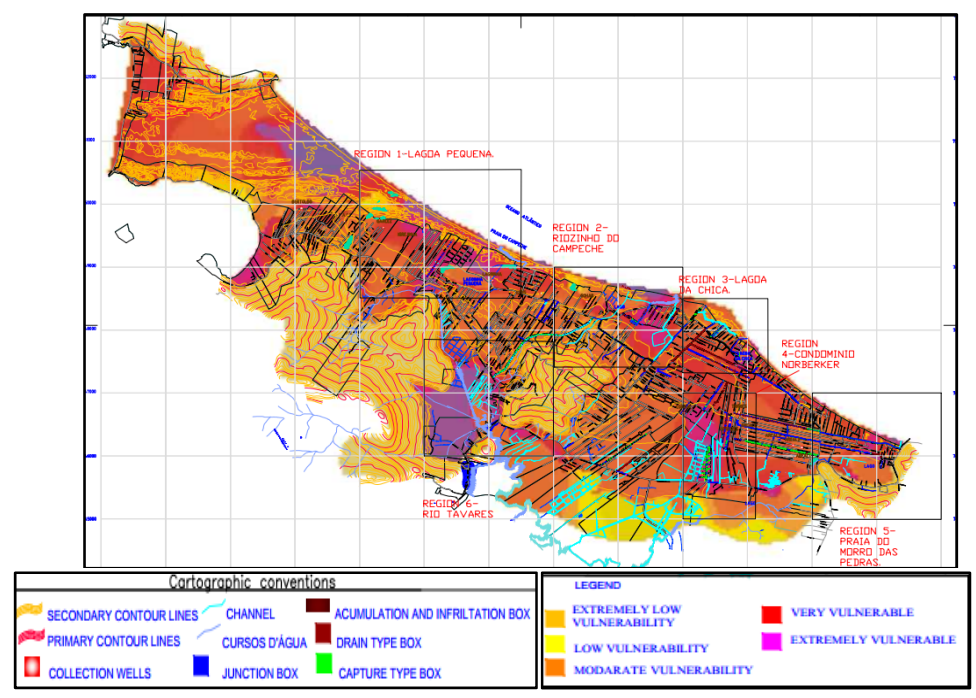

Figure 2: Synthesis map of hydrography, vulnerability and urban drainage system. 
It was not possible to conduct a detailed characterization of the drainage network due to lack of data supplied by the Municipality of Santa Catarina. However, with the aid of the satellite images on Google Earth, the paved streets were identified and then linked to a possible drainage network that was later confirmed by field observations. The Department of Public Works reported that the infiltration pits that were installed discharge water into Avenida Campeche (main access to the area), but added that, during heavy rains and high tides, the water is unable to drain away and floods the nearby streets.

\subsubsection{Region 2: Riozinho do Campeche}

The region of Riozinho do Campeche has its source in Morro do Lampião and receives stormwater and sewage effluents from important streets perpendicular to Avenida Campeche. This river has problems of illegal connections of residential sewer lines built improperly into restinga and mobile-dune areas. It is located in an area of extreme vulnerability of the aquifer. In this region, we observed wetlands, drainage ditches, and an abstraction well, as well as the straightening of some of the rivers that contribute water to the aquifer. According to the Department of Public Works, in the 1990s, a stretch of the Riozinho river was illegally channelized, causing flooding at the end of Avenida Pequeno Príncipe, the main access to Campeche Beach.

Table 2: Matrix of environmental impacts in the regions of greatest vulnerability of the Campeche aquifer.

\begin{tabular}{|c|c|c|c|c|c|c|}
\hline Regions in the synthesis map & 1 & 2 & 3 & 4 & 5 & 6 \\
\hline $\begin{array}{l}\text { Presence of wells for abstracting water from the aquifer for } \\
\text { public supply }\end{array}$ & $\mathrm{x}$ & $\mathrm{x}$ & & & $\mathrm{x}$ & $\mathrm{x}$ \\
\hline Outcrop of the aquifer in the form of a lagoon & $\mathrm{x}$ & & & $\mathrm{x}$ & & \\
\hline Burial of water bodies (lagoons or rivers or channels) & $\mathrm{x}$ & & & $\mathrm{x}$ & & \\
\hline $\begin{array}{l}\text { Illegal occupation of the area containing water resources or the } \\
\text { portion within the preservation area }\end{array}$ & $\mathrm{x}$ & $\mathrm{x}$ & $\mathrm{x}$ & $\mathrm{x}$ & & $\mathrm{x}$ \\
\hline Deforestation of resting $a$ vegetation & $\mathrm{x}$ & $\mathrm{x}$ & & & $\mathrm{x}$ & \\
\hline Clogging of lagoon beds & $\mathrm{x}$ & & & $\mathrm{x}$ & & \\
\hline Siltation of the watercourse & & & $\mathrm{x}$ & & & \\
\hline Straightening of meanders in the water & & $\mathrm{x}$ & & & & $\mathrm{x}$ \\
\hline Channelization of watercourses & & $\mathrm{x}$ & $\mathrm{x}$ & & & \\
\hline Opening of a channel connecting the lagoon with the sea & $\mathrm{x}$ & & & & & \\
\hline $\begin{array}{l}\text { Blockages or burial of the channel connecting the lagoon with } \\
\text { other water bodies }\end{array}$ & & & & $\mathrm{x}$ & & \\
\hline $\begin{array}{l}\text { Interventions in or diversion of the riverheads that contribute } \\
\text { water, thus changing the water balance and the lagoon area }\end{array}$ & & & & $\mathrm{x}$ & & \\
\hline $\begin{array}{l}\text { Use of stormwater infiltration structures in the Campeche } \\
\text { aquifer }\end{array}$ & $\mathrm{x}$ & $\mathrm{x}$ & & $\mathrm{x}$ & $\mathrm{x}$ & $\mathrm{x}$ \\
\hline Discharge of stormwater effluents directly into the river & & & $\mathrm{x}$ & & & \\
\hline Occurrence of floods & $\mathrm{x}$ & & $\mathrm{x}$ & $\mathrm{x}$ & $\mathrm{x}$ & $\mathrm{x}$ \\
\hline Presence of septic tanks & & $\mathrm{x}$ & & $\mathrm{x}$ & $\mathrm{x}$ & \\
\hline Illegal connections of sewer lines to the lagoon or river & $\mathrm{x}$ & $\mathrm{x}$ & $\mathrm{x}$ & & & \\
\hline Tidal variations that prevent stormwater runoff & $\mathrm{x}$ & & $\mathrm{x}$ & & & \\
\hline
\end{tabular}


The drainage system is composed of simple stormwater collection tanks and leaching pits, and the latter are concentrated in areas of extreme vulnerability in unsaturated zones with a prevailing thickness of 0 to $2 \mathrm{~m}$. In other words, the infiltration systems used ultimately function as methods for injecting contaminated stormwater into the Campeche aquifer.

\subsubsection{Region 3: Rio Tavares}

Rio Tavares originates in the eastern part of the Massif Central, heading south until joining the Rio Tavares mangrove. It flows from areas of high population density to areas of great biodiversity and ecological significance, such as the Rio Tavares mangrove, which is a biome protected by the Brazilian Federal Law.

Based on the mapping of the drainage network and on the available data, we detected the following sources of contamination in the region:

- Drainage system consisting of pipes and collection tanks that drain into Rio

Tavares and into part of Avenida Campeche.

- Several drainage ditches that promote infiltration in regions with outcropping of aquifer water; these ditches drain wetlands not only into the river, but also into part of the SC 406 highway, which runs across the southern portion of the Island of Florianópolis and has a high daily traffic volume.

- Stretches of Rio Tavares were channelized, promoting flooding of downstream areas.

- Floods occurring due to changes in sea-level, causing upwelling of water that obstructs the Rio Tavares channel and, in doing so, prevents stormwater from running off.

The Master Plan of Florianópolis [10] includes the construction of a Sewage Treatment Plant that will serve all of the southern portion of the Island of Florianópolis (over 100,000 inhabitants), despite the region's high aquifer vulnerability and the presence of highly sensitive biomes protected by law, such as the Rio Tavares mangrove.

\subsubsection{Region 4: Lagoa da Chica}

The very low mass points in the Lagoa da Chica region increase its vulnerability to flooding, especially in areas where drainage systems already occupy the floodhazard zone, forcing a gradual reduction of the water level over the years. This region is also characterized by the outcropping of aquifer water, and by the lack of enforcement of the guidelines for the use and occupation of land. We observed drainage installations in the lake bed in locations that have been buried.

The overlay of the drainage network map and the aquifer vulnerability map revealed that the drainage system had the following characteristics:

- It features a network composed of infiltration pits, simple collection tanks, and storage and infiltration tanks.

- There is no presence of water channels, but evidence from the Department of Public Works suggests that the channel connecting Lagoa da Chica to Riozinho do Campeche may have been buried.

The region of Lagoa da Chica is located in an area of extreme vulnerability of the Campeche aquifer, being a highly degraded environment due to the gradual 
reduction of its water level as a result of both the sedimentation caused by the erosion of nearby embankments and interventions in and diversion of water bodies that used to flow in the same direction [6]. The local population uses septic tanks, and the pollutant load is complemented by the washing of the streets, which injects these pollutants into the aquifer through leaching pits connected to a thin unsaturated zone.

\subsubsection{Region 5: Norbecker Gated Community}

The fifth region, the Norbecker Gated Community, has the largest concentration of drainage ditches that carry water to the Rio Tavares mangrove, featuring 4 wells used to abstract water for public supply and some wetland and floodhazard areas. The drainage network uses only storage tanks that discharge their effluents into drainage ditches, without any pretreatment or, at most, with the use of a geotextile fabric. In this region, infiltration basins are periodically constructed by gated communities by delimiting an area to control the flow of the stormwater effluents collected. It is noteworthy that these structures do not always work properly and occasionally cause downstream flooding.

\subsubsection{Region 6: Morro das Pedras}

The region of Morro das Pedras has three collection wells operated by CASAN, with some wetland areas and vestiges of a lake that dried up over the years. This is not an area of extreme vulnerability of the aquifer, but the presence of wells can induce the seepage of pollutants into the aquifer.

The drainage network consists of channels, galleries, simple collection tanks and leaching pits. It has a flood-hazard zone upstream of the river stretch that was straightened, which was defined as a critical area by the PMISB and contributed water to the lake that has dried up. All of the drained volume that is not discharged into the beach dunes of Morro das Pedras is disposed into this region.

\subsection{Mitigation measures for the integrated management of urban drainage systems and water resources in the District of Campeche}

By cross-checking data layers, it was possible to develop a matrix of the impacts, as shown in Table 2. This technique allows for an interdisciplinary approach to the problem and points to more comprehensive control measures. The sectorization of services such as housing, sanitation, finance, and others is a very common practice at the municipal level. While it offers managerial benefits, this practice creates difficulties in the management of urban space, especially when it comes to matters related to water resources, which are necessarily influenced by all of the processes occurring in the watershed. These issues were identified in this case study and posed problems that are difficult to tackle.

The approach to urban drainage management adopted in the study area favors a traditional perspective in which watershed management or more sustainable practices [11] are not incorporated. Practices that promote a more sustainable management of drainage systems and water resources have been increasingly recommended and studied [12-14], despite the mismatches between what is 
proposed by these studies and the actual actions taken by administrative bodies [11]. In the specific case investigated, the lack of integration between the sectors is a major gap that allows these problems to keep happening and to have a larger and larger impact on the local environment.

Based on the impacts discussed in this paper, we have established applicable mitigation measures, as listed below.

\section{Non-structural measures:}

- Designing a drainage plan for the area that integrates the macro and micro dimensions of drainage and proposes appropriate integrated solutions to the stormwater runoff problem in a tourist area with pressure on land use, a shallow aquifer, and large tidal influence.

- Qualitative and quantitative monitoring and modeling of the Campeche aquifer with a view to better understanding not only the behavior of groundwater, but also the possible impacts of the compounds present in stormwater and sewage effluents and the exploitation of water for public supply.

- Removing and relocating the population living in the flood-hazard areas of Water Bodies.

- Conducting inspections to prevent the illegal occupation of water resources.

- Controlling and supervising paving and stormwater and groundwater drainage works so that flooding problems and qualitative and quantitative changes in water resources are not aggravated.

- Actively promoting community awareness about wastewater and stormwater management practices based on Environmental Education by training, instructing, and spreading knowledge among people in the community.

- Ensuring the staff of the Municipality of Florianópolis meets the requirements of the management of urban drainage and water resources. One reason for the lack of a systematic documentation of the drainage network and related works with no local specific studies is the maldistribution of a large number of tasks among a small number of employees.

- Promoting the integration between sectors of the local government operating in industries that influence water resources.

\section{Structural measures:}

- Adequacy of stormwater infiltration structures so that they will not become a source of contamination of water resources.

- Creation of recreation areas in wetland regions and in Permanent Preservation Areas (Áreas de Preservação Permanente, APP) in order to avoid disordered occupation and assist in solving flooding problems and

- Cleaning and revitalization of silted water bodies.

\section{Conclusions and recommendations}

Studies focused on investigating the hydrological cycle in a unified manner are of great importance to the preservation and sustainability of water resources, as the current paradigm for urban planning, sanitation, use and occupation of land, 
and conservation of water supplies is deficient and creates irreversible impacts. By adopting a strategic and integrated approach to the planning of the urban environment, it is possible not only to avoid problems associated with diseases, disasters, remediation expenses, and damage, but also to provide the population with an environment with high quality of life.

The district of Campeche is a region characterized by high real estate speculation and uncontrolled population growth, resulting in irreversible impacts on the sensitive environments of its plain. Even though Campeche is rich in biodiversity, water resources, and areas for urban development, attitudes taken individually, without consulting qualified technical personnel and with no environmental planning will lead to the depletion of its water resources and the degradation of its environment. The lack of supervision by government agencies and the leniency in law enforcement are largely responsible for many of the problems found in the region.

The exploitation of groundwater for the construction of gated communities, the inappropriate use of sanitary equipment, and the channelization and straightening of surface water bodies are causing the natural lagoon environments of the region to disappear, as is the case of Lagoa da Chica.

These are all problems exacerbated by the lack of institutional unity in the city of Florianópolis, and, for this reason, drainage works are carried out without taking into account the particularities of each area. An inventory containing information on the drainage system and on all hydrographic features and infrastructure of the region should be compiled, in a standardized manner, in order for the stormwater management plan to be implemented and completed. One of the difficulties we encountered in conducting this study was merging the divergent data provided by the local administrative agencies, which led us to conclude that the government does not have the information required to properly manage sanitation, urban drainage and the environment.

\section{Acknowledgements}

The authors would like to thank CNPq (National Council of Scientific and Technological Development) for supporting Professor Alexandra Finotti' research project, Santa Catarina State Water and Sanitation Utility - CASAN, and Municipality of Florianópolis.

\section{References}

[1] Política Nacional de Recursos Hídricos, Brazil, Lei 9344 de 1997.

[2] Política Nacional de Saneamento Básico, Brazil, Lei 10.350 de 2007.

[3] Tucci, CEM. Gestão da água no Brasil- Brasília : UNESCO, 2001.156.

[4] Maidment, D. Handbook of hydrology, New York, McGraw Hill, 1993.

[5] PMISB Plano Municipal Integrado de Saneamento Básico de Florianópolis, Prefeitura Municipal de Florianópolis, 2011.

[6] Engevix. Florianópolis. Projeto de macrodrenagem do distrito do Campeche. Relatório final. Outubro, 2002. 
[7] CASAN - Companhia Catarinense de Águas e Saneamento, Estudo do Manancial Subterrâneo da Costa Leste Campeche. Município de Florianópolis. Executado por Engenharia e Pesquisas Tecnológicas. Florianópolis, 2002.

[8] Foster, SSD. and Hirata, RCA, Groundwater pollution risk assessment: a methodology using available data. WHO-PAHO/HPE-CEPIS Technical Manual, Lima, Peru, 1998.

[9] Barbosa, Tereza Cristina Pereira, Adote a Lagoa Pequena: relatório final do projeto de extensão da UFSC. Florianópolis: 1999.

[10] Florianópolis. Plano Diretor Participativo do Município - Leitura Integrada da Cidade, Florianópolis: IPUF, 2008.

[11] Cettner, A.; Ashley, R.; Hedstrom, A. and Viklander, M. Sustainable development and urban stormwater practice. Urban water journal, 11(3), pp. 185-197, 2014.

[12] Doubleday, G.; Sebastian, A.; Luttenschlager, T. and Bedient, P.B. Modeling hydrologic benefits of low impact development: a distributed hydrologic model of the Woodlands, Texas. Journal of the American Water Resources Association, 49(6), pp. 444-1455, 2013.

[13] Qin, H.; Li, Z. and Fu, G. The effects of low impact development on urban flooding under different rainfall characteristics. Journal of Environmental Management, 129, pp. 577-585, 2013.

[14] Ellis, J.B.; Revitt, D.M. and Lundy, L. An impact assessment methodology for urban surface runoff quality following best practice treatment. Science of the Total Environment, 416, pp. 172-179, 2012. 